\title{
Notification that New Names and New Combinations Have Appeared in Volume 46, No. 3, of the IJSB ${ }^{a}$
}

\begin{tabular}{|c|c|c|c|}
\hline Name: & Proposed as: & Authors: & $\begin{array}{l}\text { USSB reference } \\
\text { description: }\end{array}$ \\
\hline Legionella waltersii & sp. nov. & Benson et al. & $46(3): 633$ \\
\hline Streptomyces caviscabies & sp. nov. & Goyer et al. & 46(3):638 \\
\hline Actinobacillus delphinicola & sp. nov. & Foster et al. & $46(3): 652$ \\
\hline Enterococcus seriolicida pro synon. Lactococcus garvieae & synon. & Teixeira et al. & 46(3):667 \\
\hline Mycobacterium hodleri & sp. nov. & Kleespies et al. & 46(3):686 \\
\hline Paenibacillus apiarius & sp. nov. & Nakamura & 46(3):692 \\
\hline Streptomyces biverticillatus pro synon., Streptomyces baldaccii & synon. ${ }^{b}$ & Labeda & 46(3):702 \\
\hline Streptomyces fervens pro synon., Streptomyces baldaccii & synon. ${ }^{b}$ & Labeda & $46(3): 702$ \\
\hline Streptomyces roseoverticillatus pro synon., Streptomyces baldaccii & synon. $^{b}$ & Labeda & 46(3):702 \\
\hline Streptomyces kentuckensis pro synon., Streptomyces netropsis & synon. & Labeda & 46(3):702 \\
\hline Streptomyces flavopersicus pro synon., Streptomyces netropsis & synon. & Labeda & 46(3):702 \\
\hline Streptomyces distallicus pro synon., Streptomyces netropsis & synon. & Labeda & 46(3):702 \\
\hline Streptomyces ladakanum pro synon., Streptomyces mobaraensis & synon. & Labeda & 46(3):702 \\
\hline Bartonella vinsonii & emend. & Kordick et al. & 46(3):708 \\
\hline Bartonella vinsonii subsp. berkhoffii & subsp. nov. & Kordick et al. & 46(3):708 \\
\hline Bartonella vinsonii subsp. vinsonii & Rule $46^{c}$ & & \\
\hline Desulfovibrio gabonensis & sp. nov. & Tardy-Jacquenod et al. & 46(3):714 \\
\hline Mycoplasma sturni & sp. nov. & Forsyth et al. & 46(3):719 \\
\hline Enwinia alni & sp. nov. & Surico et al. & $46(3): 725$ \\
\hline Methanococcus deltae pro synon., Methanococcus maripaludis & synon. & Keswani et al. & 46(3):734 \\
\hline Treponema maltophilum & sp. nov. & Wyss et al. & 46(3):751 \\
\hline Clostridium proteoclasticum & sp. nov. & Attwood et al. & 46(3):755 \\
\hline Bacillus sporothermodurans & sp. nov. & Petterson et al. & $46(3): 763$ \\
\hline Micromonosporaceae & emend. & Koch et al. & $46(3): 767$ \\
\hline Streptococcus dysgalactiae subsp. dysgalactiae & Rule $46^{d}$ & & \\
\hline Streptococcus dysgalactiae subsp. equisimilis & subsp. nov. & Vandamme et al. & $46(3): 780$ \\
\hline Staphylococcus saprophyticus subsp. bovis & subsp. nov. & Hájek et al. & 46(3):793 \\
\hline Staphylococcus saprophyticus subsp. saprophyticus & Rule $46^{c}$ & & \\
\hline Spiroplasma syrphidicola & sp. nov. & Whitcomb et al. & 46(3):799 \\
\hline Herbaspirillum & emend. & Baldani et al. & 46(3):808 \\
\hline Herbaspirillum seropedicae & emend. & Baldani et al. & 46(3):808 \\
\hline $\begin{array}{l}\text { Herbaspirillum rubrisubalbicans (basonym Pseudomonas } \\
\text { rubrisubalbicans) }\end{array}$ & comb. nov. & Baldani et al. & 46(3):809 \\
\hline Sanguibacter inulinus & sp. nov. & Pascual et al. & 46(3):812 \\
\hline Picrophilaceae & fam. nov. & Schleper et al. & 46(3):814 \\
\hline Picrophilus & gen. nov. & Schleper et al. & 46(3):814 \\
\hline Picrophilus oshimae & sp. nov. & Schleper et al. & $46(3): 815$ \\
\hline Picrophilus torridus & sp. nov. & Zillig et al. & 46(3):816 \\
\hline Salinivibrio & gen. nov. & Mellado et al. & 46(3):820 \\
\hline Salinivibrio costicola (basonym Vibrio costicola) & comb. nov. & Mellado et al. & 46(3):820 \\
\hline Polaromonas & gen. nov. & Irgens et al. & 46(3):825 \\
\hline Polaromonas vacuolata & sp. nov. & Irgens et al. & $46(3): 825$ \\
\hline Alcaligenes faecalis subsp. faecalis & Rule $46^{f}$ & & \\
\hline Staphylococcus schleiferi subsp. schleiferi & Rule $46^{g}$ & & \\
\hline Pediococcus acidilactici & Designation of neotype strain & Opinion 68 & 46(3):835 \\
\hline Helicobacter bizzozeronii & sp. nov. ${ }^{h}$ & Hänninen et al. & $46(3): 839$ \\
\hline
\end{tabular}

a This listing of names published in a previous issue of IJSB is provided as a service to bacteriology to assist in the recognition of new names and new descriptions. This procedure was proposed by the Judicial Commission [Minute II (ii), Int. J. Syst. Bacteriol. 41:185, 1991]. The names given herein have priority according to the issue of the IJSB in which they were published.

${ }^{b}$ Under Principle 6 and Rule 24b (1) of the International Code of Nomenclature of Bacteria, the proposal of $S$. biverticillatus, $S$. fervens, and $S$. roseoverticillatus as junior synonyms of $S$. baldaccii is illegitimate. Since the senior epithet is roseoverticillatus, $S$. baldaccii, $S$. biverticillatus, and $S$. fervens are to be regarded as junior synonyms of $S$. roseoverticillatus.

${ }^{c}$ According to Rule 46 of the International Code of Nomenclature of Bacteria, the valid publication of Bartonella vinsonii subsp. berkhoffii automatically creates another subspecies Bartonella vinsonii subsp. vinsonii (Weiss and Dasch 1982) Brenner et al, 1993 emend. Kordick et al. 1996.

${ }^{d}$ According to Rule 46 of the International Code of Nomenclature of Bacteria, the valid publication of Streptococcus dysgalactiae subsp. equisimilis automatically creates another subspecies Streptococcus dysgalactiae subsp. dysgalactiae Garvie et al. 1983.

${ }^{e}$ According to Rule 46 of the International Code of Nomenclature of Bacteria, the valid publication of Staphylococcus saprophyticus subsp. bovis automatically creates another subspecies Staphylococcus saprophyticus subsp. saprophyticus (Fairbrother 1940) Shaw et al. 1951.

${ }^{f}$ According to Rule 46 of the International Code of Nomenclature of Bacteria, the valid publication of Alcaligenes faecalis subsp. homari automatically creates another subspecies Alcaligenes faecalis subsp. faecalis Castellani and Chalmers 1919. For the sake of completeness of records, the automatic creation of the subspecies is pointed out by Euzéby in IJSB 46:830.

${ }^{g}$ According to Rule 46 of the International Code of Nomenclature of Bacteria, the valid publication of Staphylococcus schleiferi subsp. coagulans automatically creates another subspecies Staphylococcus schleiferi subsp. schleiferi Freney et al. 1988. For the sake of completeness of records, the automatic creation of the subspecies is pointed out by Euzéby in IJSB 46:830.

${ }^{h}$ In the description of Helicobacter bizzozeronii sp. nov. by Hänninen et al. (IJSB 46:165) no type strain is specified. CCUG 35045 is designated as the type strain by way of an Erratum. 